\title{
Design of Telegram Assisted E-Work Team Based Blended Learning in Entrepreneur Learning
}

\author{
Diana Pramesti ${ }^{1,}$ Adevia Indah Kusuma ${ }^{2}$
}

\author{
${ }^{1}$ Primary School Teacher Education, University Muhammadiyah Bangka Belitung, Bangka Belitung 33684, Indonesia \\ ${ }^{2}$ Primary School Teacher Education, University Muhammadiyah Bangka Belitung, Bangka Belitung 33684, Indonesia \\ *Corresponding author. Email: diana.pramesti@stkipmbb.ac.id; adevia.indahkusuma@stkipmbb.ac.id
}

\begin{abstract}
The background of this research were: (1) optimizing the learning subject potential and optimize the use of technology to support learning; (2) discipline students in collecting assignments; (3) directing students to get a relevance of references to supporting their assignments; (4) improve student literacy in scientific articles or journals; (5) to support the creative economy of Government programs that was introduced in the education field through entrepreneur learning. Moreover, this study to support Government policy about work from home (WFH) and school from home (SFH) to preventive measure dissolution of Covid-19 distribution. This opportunities for the students could be survive in the globalization and industrial revolution 4.0. Accordingly the study was very important to do. This study aimed to determine the feasibility of telegram-assisted e-work teams based blended learning in entrepreneurship learning for STKIP MBB students. This was a developmental research model research and development according to ADDIE, involving five stages: 1) Analysis; 2) Design; 3) Development; 4) Implementation, and 5) Evaluation. This development of this product was based on a Learning Management System (LMS) using Moodle through an e-learning website was gnomio. This study cased limited to the design and development stage. The data were collected through questionnaires of advisability telegram assisted e-work team based blended learning from expert judgment. The result of this study showed that teaching material could be used for entrepreneur learning, moreover entrepreneur learning material and media were included good category.
\end{abstract}

Keywords: Telegram, E-Work Team, Blended Learning, Entrepreneurship Learning

\section{INTRODUCTION}

Entrepreneurship course are compulsory subjects that must be taken by University of Muhammadiyah Bangka Belitung students. The aimed of this course to growth entrepreneurial spirit in student to be able to surviving the global challenges. Moreover this course has improve pedagogical techniques of lecturers to involving both entrepreneurship and higher education learning processes [1]. The aimed to academic context were to understand the role academic process of designing, implementing, monitoring and asessing in their experiences on learning [2]. The students on higher education are required to facilitate especially for the give respond to the social and economic needs of society [3] and to be a solution for problems faced [4]. Curriculum in UNMUH BABEL relevant with the needs and condition in society. Furthermore, the graduates from UNMUH BABEL could be benefit society and implement their abilities in everyday life.

Based on interview with the entrepreneur lecturer in UNMUH BABEL to known the lecturer has a problem for undertanding and respontibility asessment. So far, entrepreneurial learning uses project based learning for improve their ability through a group task project, such as finance, marketing, management of project, etc. During the project learning showed that their communication was passably category on collecting individual tasks or report of their project. Moreover, the others factor were reports that are made were not structured and need for guidance in making reports on business activities.

Covid-19 pandemic phenomena that occur globally have a direct impact on education and learning that require immediate problem solving. The important thing of this phenomenon is a challenge for educators to innovate and be creative in made a learning design. Innovation for educators in creating media to made it learning media by combining several elements through virtual technology [5]. Furthermore, including the strategy of organizing teaching, teaching delivery and the quality of appropriate teaching [6]. The challenge in this condition is to choose adaptive and flexible learning model to be applied in the learning process by blended learning. Blended learning is a learning strategy that aimed to support the achievement of learning goals that combine learning in the classroom with outside the classroom [7].

This study use telegram as a tool for students to receive material that must be studied along with instructions on the assignments, that learning is more structured. This telegram as an innovation in optimizing utilizing social media and learning as problem solving [8] can support 
learning in institutions [9] and provide perceptual experiences in learning [10] through a smartphone or mobile phone application that is implemented in learning anywhere and anytime [11]. Students could discussion about learning materials via telegram, moreover telegram could be carried out anywhere and at any time, that is not limited by space and time in accordance with the nature of m-learning.

The basis that supports the program to optimize learning is to use the Learning Management System (LMS) in particular developing e-work teams. LMS was dynamic and practical for use in an institution [12] which can be useful in improving student learning experiences and training in building a mindset for students [13], trained to manage a system in education [14], improve pedagogical competence in learning, and made learning effective at the tertiary level [15]. LMS helps and supports educators including lecturers in online interaction and building a collaborative learning environment, both blended learning in face to face or online [16].

The background of this research were: (1) optimizing the learning subject potential and optimize the use of technology to support learning; (2) discipline students in collecting assignments; (3) directing students to get a relevance of references to supporting their assignments; (4) improve student literacy in scientific articles or journals; (5) to support the creative economy of Government programs that was introduced in the education field through entrepreneur learning. Based on the problems and reviews, this study serves to optimizing implementation of entrepreneurship learning. Moreover, to support Ministry of Education and Culture or Regional Government to efforts for break the Covid-19 distribution chain, that it applies School from Home (SFH) and Work from Home (WFH).

\subsection{Related Work}

According to the product (telegram assisted-work team based blended learning), we divided the existed work into three categories.

\subsubsection{Analysis}

Analysis phase before creating the plan, developing, or even implementing [17] which did analysing of evaluation result of the previous training program form student's and lecturer competencies [18]. Moreover, in this phase is the foundation for all other phases of instructional design, included specific research techniques and the output of this phase often include the instructional goals [19].

Based on the result of need analysis or need assessment showed that during the project learning showed that their communication was passably category on collecting individual tasks or report of their project. Moreover, the others factor were reports that are made were not structured and need for guidance in making reports on business activities. One of the learning component must be support in learning process is teaching material and media. This is important thing to support online learning, accordingly would impact directly or indirectly especially for entrepreneurship learning.

Moreover, based on this situation during pandemic Covid-19 and New Normal Era, the Ministry Education and Cultural or the Regional Government has a policy to implementation School from Home $(\mathrm{SCH})$ and Work from Home (WFH). It's mean education and learning field shifting from conventional method to be virtual methods (online learning).

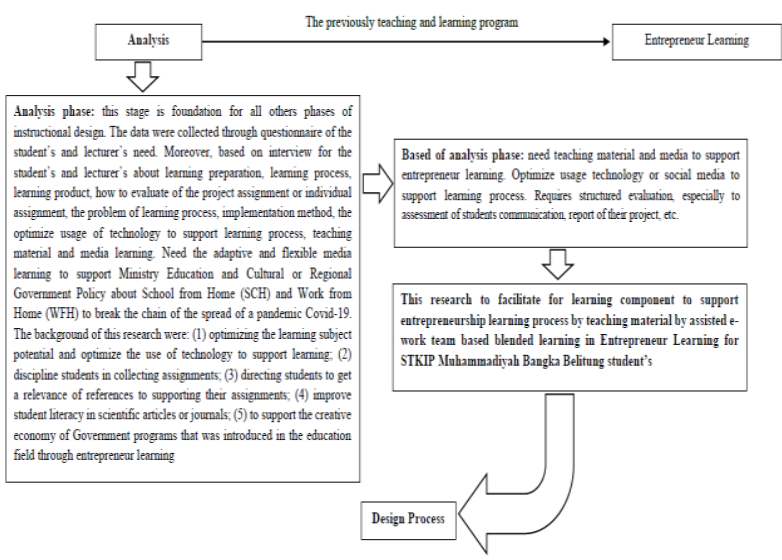

Figure 1. Schema of Analysis before developing this product

The schema to showed that need analysis or need assessment of entrepreneur learning before to developing this product. The result of analysis from student's and lecturer's need assessment questionnaire and interview with the learning subject.

\subsubsection{Design}

Design phase is really how to applying the instruction could really be effective [17] to made it prototype specification [19] of this product. Based on analysis, the researchers to made it prototype of teaching material. The development of teaching material is work sheet, in this study did a modification of teaching material to be e-work team but not changes of main component of teaching material. E-work sheet instruction implemented by optimizing social media application (telegram). This innovation by mobile learning could be alternative to improve the student's motivation [20] in entrepreneur learning.

Telegram is one of innovation as a social media tools for teaching and learning in institution [9] especially in STKIP Muhammadiyah Bangka Belitung. The aimed of this research to optimizing telegram application for teaching and learning, moreover in this application could to inserting of curriculum, syllabus, and technology [11]. Telegram application support to enhancement by providing a quick way and easy platform to sharing information [21] form learning subject, and other aimed based on telegram application has various pedagogical benefits and instruction 
effectively for [22] formal or non-formal learning implementation and has contribute to reflection on the added value of collaborative work [2]. This phase to made design prototype of product such as layout, learning objective, learning instruction to implemented in telegram and inserting in Learning Management System (LMS) with Gnomio open source platform Moodle. Moreover, this product could sign in by website.

Implementation for this product using principal of blended learning. Blended learning is mixed method of traditional classroom teaching methods with online learning [5] the aimed of this study to support technology development in $21^{\text {st }}$ century [6]. Moreover, this is learning innovation to improve self reliance and self confidence to explore learning method in this era [7], to support preceded modern instructional technologies and educational experiences [23]. This product of telegram assisted e-work team based blended learning to support professional development programs to implementation on higher education, could be completed as a stand-alone professional development course [24]. The assumption of design product:

\begin{tabular}{|c|c|}
\hline \multicolumn{2}{|c|}{ COVER PAGE } \\
\hline \multicolumn{1}{|c|}{ Login } \\
\hline $\begin{array}{c}\text { Deadline date of } \\
\text { assignment } \\
\text { Account and } \\
\text { menu }\end{array}$ \\
\hline $\begin{array}{c}\text { Site } \\
\text { administrator }\end{array}$ \\
\hline Subject Matter \\
\hline $\begin{array}{c}\text { Calender and } \\
\text { has a sign for } \\
\text { deadline date }\end{array}$ \\
\hline Online user \\
\hline
\end{tabular}

Figure 2. Design of product development

Design phase of this study aimed to make it prototype of product development. This design would be implementation on development phase.

\subsubsection{Developing}

In this phase, the researcher to creating factual sample for instructional design, developing the materials of the course, and run through the conduction of the design.
Developing phases to generate and validate the learning resources of product to developing, generate content, select and developing supporting media, developing of guidance for the student's, lecturer's, conduct formative revisions, and conduct a pilot test [18]. Moreover, this stage aimed to generate the lesson plans and lesson materials. During this phases the researcher will develop the instruction and supporting documentation [19]. You can access this product in https://entrepreneurlearning.gnomio.com/my/. The assumption of developing product:

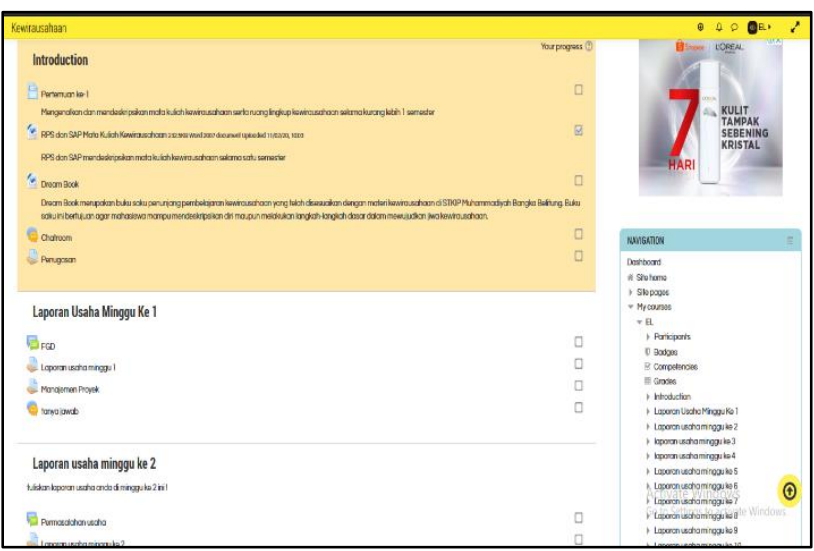

Figure 3. Developing of product development

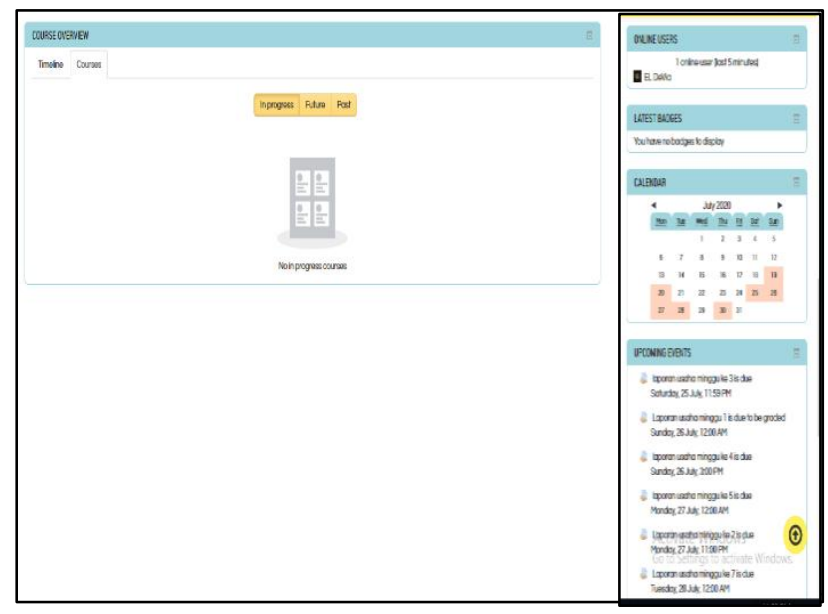

Figure 4. Developing of product development

\subsection{Our Contribution}

This paper contributes to complementing the needs of lecturer's and student's in entrepreneur learning. This product is telegram assisted e-work team based blended learning would be validation test by expert judgment and peer reviewer. The aspect validation of this product were entrepreneur material and media. Based on the entrepreneur material expert validation showed that the material is good category. Based on the media expert validation to showed that for the aspect of display quality and language is good category, aspect of ease for process operation is passably 
category, aspect of reliability is good category, illustrative quality aspects (pictures, videos or animations) is passably, and aspect of easy of use is good category. Through several the cases and the result, it is shown that our improvements are feasible and efficient to support entrepreneur learning.

\subsection{Paper Structure}

The rest of the paper is organized as follows. Section 2 introduces the preliminaries used in this paper, which include important to developing this product to support entrepreneur learning, optimizing telegram as learning tool, would be implemented based blended learning, and differences this study with the others study. Moreover the result of expert judgment on descriptive analysis as based on to revision of product. The end of this part is conclusion of this study.

\section{BACKGROUND}

\subsection{Background of Product Development}

The background of this study were: (1) optimizing the learning subject potential and optimize the use of technology to support learning; (2) discipline students in collecting assignments; (3) directing students to get a relevance of references to supporting their assignments; (4) improve student literacy in scientific articles or journals; (5) to support the creative economy of Government programs that was introduced in the education field through entrepreneur learning. Moreover, this study to support Government policy about work from home (WFH) and school from home (SFH) to preventive measure dissolution of Covid-19 distribution. This chance for the students could be surviving in the globalization and industrial revolution 4.0. Accordingly the study was very important to do.

\subsection{The Characteristic of this Study}

The characteristic of this study to developing telegram assisted e-work team based blended learning in entrepreneur learning. Preliminary research to maximizing telegram application for teaching reading [11], has a same and differences both of study. The same variable and using telegram as a media for teaching and learning process. The differences aspect are subject matter and using LMS in product development. Learning implementation based on blended learning.

LMS: the game changer for traditional teaching and learning at adult and higher education institutions to show that positives and optimistic responses of students for management system preference, utilization, appreciation, and satisfaction, for online teaching-learning at higher education institutions [12]. The same aspect this study with product development is using LMS to be learning media. The characteristic of product development is optimizing social media (telegram) to be a tools for entrepreneur learning for interactive learning and to direct learning process.

\subsection{Telegram Assisted E-Work Team Based Blended Learning}
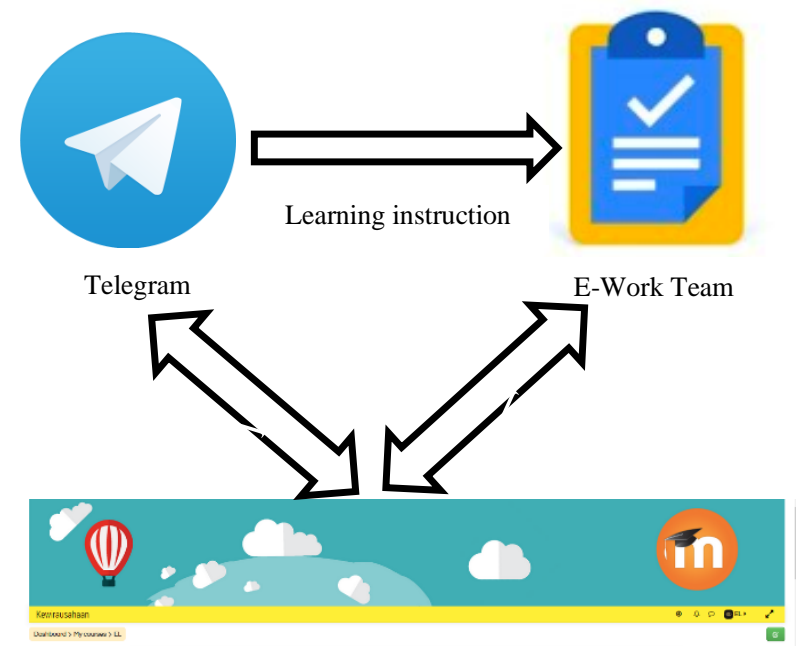

LMS: https://entrepreneurlearning.gnomio.com/my/

Figure 5. The schematic of telegram assisted e-work team based blended learning in entrepreneur learning

Telegram as a social media to be a learning tool. The aimed of using telegram is give the instruction for the group class for learning would begin. Features in LMS there topic of learning, FGD (Forum Group Discussion) for discussion about special topic of learning, Chat features for chit chat with one each others to preparation check before learning would begin. Assignment feature for upload some of their tasks. Based some of features LMS completely online learning. Moreover, there online user feature for to check who is not presence for entrepreneur learning each meeting. This product not just support to be media but helped the lecturer's to improve their pedagogic competencies. How the lecturer's could design of learning process.

\subsection{Result of This Product Development}

The categorization of the results could be seen in the following Table 1. 
Table 1. The categorization of decision

\begin{tabular}{|c|c|}
\hline Range & Category \\
\hline$\leq 40$ & Dissatisfactory \\
\hline $41-60$ & Passably \\
\hline $61-80$ & Good \\
\hline $81-100$ & Satisfactory \\
\hline
\end{tabular}

Source: [25]

Based on the validation result by expert judgment to showed that:

Table 2. The validation result of Entrepreneur Material Expert Judgment

\begin{tabular}{|c|c|c|}
\hline $\begin{array}{c}\text { Material Expert } \\
\text { Judgment }\end{array}$ & $\begin{array}{c}\text { Percentage } \\
(\%)\end{array}$ & $\begin{array}{c}\text { Category and } \\
\text { Descriptive }\end{array}$ \\
\hline $\begin{array}{l}\text { Aspect of } \\
\text { Material } \\
\text { Worthiness and } \\
\text { Material } \\
\text { Accuracy }\end{array}$ & 62 & Good \\
\hline $\begin{array}{l}\text { Material } \\
\text { presentation } \\
\text { aspects }\end{array}$ & 67 & Good \\
\hline $\begin{array}{l}\text { Aspects of the } \\
\text { Relevance of } \\
\text { Facts to the } \\
\text { Concept of } \\
\text { Entrepreneurship }\end{array}$ & 63 & $\begin{array}{l}\quad \text { Good (after } \\
\quad \text { revision) } \\
\text { Suggestion: } \\
\text { adjusted to } \\
\text { needs of } \\
\text { students and the } \\
\text { potential that is } \\
\text { available }\end{array}$ \\
\hline $\begin{array}{l}\text { Language } \\
\text { aspects }\end{array}$ & 63 & Good \\
\hline Didactic aspect & 69 & Good \\
\hline $\begin{array}{l}\text { Constructive } \\
\text { aspect }\end{array}$ & 64 & Good \\
\hline Technique aspect & 73 & Good \\
\hline \multicolumn{2}{|c|}{ Total } & Good \\
\hline
\end{tabular}

Table 3. The validation result of Media Expert Judgment

\begin{tabular}{|l|c|c|}
\hline $\begin{array}{c}\text { Media Expert } \\
\text { Judgment }\end{array}$ & Percentage (\%) & Category \\
\hline $\begin{array}{l}\text { Display and } \\
\text { Language } \\
\text { Quality Aspects }\end{array}$ & 75 & Good \\
\hline $\begin{array}{l}\text { Aspect of Ease } \\
\text { of Operation } \\
\text { Process }\end{array}$ & 58 & Passably \\
\hline $\begin{array}{l}\text { Reliability } \\
\text { aspects }\end{array}$ & 75 & Good \\
\hline
\end{tabular}

\begin{tabular}{|l|c|c|}
\hline $\begin{array}{c}\text { Media Expert } \\
\text { Judgment }\end{array}$ & Percentage (\%) & Category \\
\hline $\begin{array}{l}\text { Illustrative } \\
\text { Quality Aspects } \\
\text { (pictures, videos } \\
\text { or animations) }\end{array}$ & 50 & Passably \\
\hline $\begin{array}{l}\text { Aspects of Ease } \\
\text { of Use }\end{array}$ & 75 & Good \\
\hline \multicolumn{2}{|c|}{ Total } & Good \\
\hline
\end{tabular}

Based on the result showed that the aspect of the relevance of facts to the concept of entrepreneurship has a good after revision of e-work team. Based on suggestion of expert validation e-work team not relevance with the student's need and not yet to showed the student's can to improve their potential. Although e-work team has to showed for the technical didactic learning process.

Based on media expert judgment to show there two aspect in a passably. The suggestion of expert judgment more than clear for instruction's learning, how start to begin and give explanation to describe each of features. Illustrative quality aspects (pictures, videos or animations) in passably category, based on media not able video to support learning.

Telegram is a valuable extension of classical learning methods [9] to be innovation for teaching and learning and would be problem solving for educators [8]. ICT is a media to supporting distance learning [26], one of the open source platform to be considered is Moodle. LMS support constructionist of pedagogical principle of educators and could be made to the source code as long as the original license [26]-[28].

\section{CONCLUSION}

The conclusion of this study are the telegram e-work team based blended learning was proper to teach material of entrepreneur learning, in terms entrpreneur material (aspect of material wothiness and material accuracy, material presentation aspect, aspect of the relevance of facts to the concept of entrepreneurship, language aspects, didactic aspect, constructive aspect, and technique aspect). Moreover media aspect (display and language quality aspects, aspect of base of operation process, reliability aspect, illustrativequality aspects, and aspect of easy of use. All of the validation to showed that this teaching material and media is good category.

Based on the results of this research to show that the media developed could helped entrepreneurial learning and could be used as supporting media for blended learning with the features that have been available, such as to improve the students disciplinary through task deadline. Furthermore, the lecturer could be control students cognitive through by quiz feature, the individual or group project could be upload in this media for evidence of their activities, the lecturer 
could be effective discussion for students by chat or forum group discussion in this media features and the lecturer could be control students activities, give a feed back, to assignment student activities or task.

\section{ACKNOWLEDGMENT}

This work was supported by LPPM UNMUH BABEL and Ministry of Research, Technology, and Higher Education, and all of the team to support this research.

\section{REFERENCES}

[1] K. Moustaghfir and N. T. Sirca, "Entrepreneurial Learning in Higher Education: Introduction to the Thematic Issue," Int. J. Euro-Mediterranean Stud., vol. 3, no. 1, pp. 3-26, 2010.

[2] A. P. Marques, A. I. Couto, and P. Rocha, "Entrepreneurial Learning in Higher Education: Perceptions, Realities and Collaborative Work from the Stakeholder Point of View," Eur. J. Soc. Sci. Educ. Res., vol. 5, no. 1, p. 255, 2015, doi: 10.26417/ejser.v5i1.p255-262.

[3] M. Wain, J. Devine, A. Ferrari, Z. Jávorka, and V Mobilio, "The Entrepreneurial and Innovative Higher Education Institution. A Review of the Concept and Its Relevance Today," Heinnovate, no. June, pp. 1-16, 2018, doi: 10.2791/593884.

[4] R. Ardianti, "Entrepreneurship Education in Indonesia's Higher Education Institutions: A Solution for Problems Faced by The Next Generation," London Int. Conf. Educ. (LICE2009), UK, pp. 119-123, 2009, [Online]. Available: http://repository.petra.ac.id/16848/1/Publikasi1_0 5001_1747.pdf [ accessed: Januari 7, 2019].

[5] Martha Cleveland-Innes dan Dan Wilton, Guide to Blended Learning, vol. 7, no. 6B. Canada: Athabasa University, 2016.

[6] D. N. Wardani, A. J. E. Toenlioe, and A. Wedi, "Daya Tarik Pembelajaran Di Era 21 Dengan Blended Learning," J. Kaji. Teknol. Pendidik., vol. 1, no. 1, pp. 13-18, 2018.

[7] I. K. Widiara, "Blended Learning Sebagai Alternatif Pembelajaran di Era Digital," Purwadita, vol. 2, no. 2, pp. 50-56, 2018.

[8] Z. H. Iksan and S. M. Saufian, "Mobile Learning: Innovation in Teaching and Learning Using Telegram," Int. J. Pedagog. Teach. Educ., vol. 11, no. 1, pp. 19-26, 2012.
[9] N. N. Yinka, Adesope Rebecca Queendarline, "Telegram as a social media tool for teaching and learning in tertiary institutions," Int. $J$. Multidiscip. Res. Dev., vol. 5, no. 7, pp. 95-98, 2018, [Online]. Available: www.allsubjectjournal.com.

[10] Z. A. Abu-Ayfah, "Telegram App in Learning English: EFL Students' Perceptions," English Lang. Teach., vol. 13, no. 1, p. 51, 2019, doi: 10.5539/elt.v13n1p51.

[11] F. M. Sari, "Maximizing telegram application for teaching reading," 4th UAD TEFL Int. Conf. UAD Yogyakarta 2017, pp. 228-233, 2017.

[12] L. Reid, "Learning Management Systems : The Game," Glob. J. Human-Social Sci. G Linguist. Educ., vol. 19, no. 6, 2019, doi: 10.34257/GJHSSGVOL19IS6PG1.

[13] N. N. M. Kasim and F. Khalid, "Choosing the right learning management system (LMS) for the higher education institution context: A systematic review," Int. J. Emerg. Technol. Learn., vol. 11, no. 6, pp. 55-61, 2016, doi: 10.3991/ijet.v11i06.5644.

[14] S. M. Joel, "Learning Management System success : Increasing Learning Management System usage in higher education in sub-Saharan Africa Joel S . Mtebe," Int. J. Educ. Dev. Using Inf. Commun. Technol., vol. 11, no. 2, pp. 51-64, 2015 .

[15] C. K. Chen and M. N. Almunawar, "Cloud Learning Management System in Higher Education," no. September 2015, pp. 29-51, 2019, doi: 10.4018/978-1-5225-7473-6.ch002.

[16] D. G. Sampson and P. Zervas, "Mobile Learning Management Systems in Higher Education," Virtual Learn. Environ., no. October, pp. 12491264, 2012, doi: 10.4018/978-1-4666-00119.ch608.

[17] N. Aldoobie, “ADDIE Model,” Am. Int. J. Contempporary Res., vol. 5, no. 6, pp. 68-72, 2015.

[18] T. Prastati and A. I. Tarigan, "Implementing The Addie Model For UT' s Tutor Training Program," Teach. Learn. 21st Century Challenges Lect. Teach., pp. 330-336, 2014.

[19] S. J. McGriff, "Instructional System Design ( ISD ): Using the ADDIE Model Instructional System Design ( ISD ): Using the ADDIE Model," Instr. Syst. Coll. Educ. Penn State Univ., 2000.

[20] D. R. M. Winda Purnama Sari, "Jurnal Pendidikan Biologi," J. Pendidik. Biol., vol. 7, no. 1, pp. 3543, 2017, doi: 
https://doi.org/10.24114/jpb.v8i1.11224.

[21] U. Perlis et al., "Teaching and Learning Enhancement Based on Telegram Social Media Tool," J. Intelek, vol. 11, pp. 7-11, 2016.

[22] S. Vahdat and F. Mazareian, "The Impact of Telegram on Learning of Collocational Knowledge among EFL High School Students," ALR J., vol. 4, no. 03, pp. 37-51, 2020, doi: 10.14744/alrj.2020.18189.

[23] C. Dziuban, C. R. Graham, P. D. Moskal, A. Norberg, and N. Sicilia, "Blended learning: the new normal and emerging technologies," Int. J. Educ. Technol. High. Educ., vol. 15, no. 1, pp. 116, 2018, doi: 10.1186/s41239-017-0087-5.

[24] D. Bath and J. Bourke, Blended Learning Getting Started With. 2010.

[25] Suharsimi Arikuto, Dasar-dasar Evaluasi Pendidikan. Jakarta: Bumi Aksara, 2009.

[26] Kementerian Pendidikan Malaysia, "Laporan Awal Pelan Pembangunan Pendidikan Malaysia 2013 - 2025,” 2012.

[27] M. N. A. M. A. Embi, in E-Pembelajaran di IPTA Malaysia, 1st ed. UKM Bangi, 1st ed. Malaysia: Pusat Pembangunan Akademik Universiti Kebangsaan Malaysia \& Jabatan Pengajian Tinggi Kementerian Pengajian Tinggi Malaysia., 2010.

[28] M. Omar, "Moodle dan Sistem Pengurusan Pembelajaran," Online Submission, 2015. http://documents.tips/documents/moodle-dansistem-pengurusanpembelajaran.\%0Ahtml. 